\title{
Procalcitonin in infectious diseases: a bibliometric analysis
}

\author{
Yajun Zhang ${ }^{1 \#}$, Jinhui Zhang ${ }^{2 \#}$, Li Zhao ${ }^{1}, \mathrm{Na} \mathrm{Zhao}^{1}$, Ye Zhang ${ }^{1}$, Jie Zhang $^{3}$, Shuying Wang ${ }^{4}$ \\ ${ }^{1}$ Department of Laboratory, Beijing Renhe Hospital, Beijing, China; ${ }^{2}$ Department of Laboratory, Laboratory of Changli People's Hospital, Changli, \\ China; ${ }^{3}$ Laboratory of Peking University International Hospital, Beijing, China; ${ }^{4}$ PLA Medical College, Beijing, China \\ Contributions: (I) Conception and design: Y Zhang, J Zhang; (II) Administrative support: J Zhang; (III) Provision of study materials or patients: \\ L Zhao, N Zhao; (IV) Collection and assembly of data: Y Zhang, S Wang; (V) Data analysis and interpretation: Y Zhang, J Zhang, S Wang; \\ (VI) Manuscript writing: All authors; (VII) Final approval of manuscript: All authors. \\ "These authors contributed equally to this work. \\ Correspondence to: Jie Zhang. Laboratory of Peking University International Hospital, Beijing, China. Email: 2575797834@qq.com.
}

\begin{abstract}
Background: Infectious disease is ubiquitous and can represent a major threat to human health. Procalcitonin (PCT) is mainly used to identify the severity of bacterial infections, which can be secondary to many non-bacterial infectious diseases. The purpose of this study was to evaluate current research in the field of infectious diseases and to suggest directions for further investigation.

Methods: The Science Citation Index Expanded (SCI-E) database in the Web of Science Core Collection (WOSCC) was used as the search data source. The search parameters including the search scope were limited to "infectious disease" and the search term was "procalcitonin". The time range of the target literature was 1900 to the final search date of this research (May 7, 2021), and the language was limited to English. The full records of the search results and cited references were exported in plain text format, and Citespace software was used to analyze the documents.

Results: A total of 996 related research documents were found, and the number increased significantly in 2020. The United States, Germany, and the United Kingdom were the main sources of research, and the main research institutions were Aarhus University Hospital and Harvard University. The main journals are publishing material were Clin Infect Dis, Lancet, and Crit Care Med. Analysis of key words showed that the most common current research topics were sepsis and biomarkers of disease monitoring.
\end{abstract}

Conclusions: Research on infectious disease and the role of PCT is increasing. The main research topics are sepsis and biomarkers for disease monitoring.

Keywords: Procalcitonin; infectious diseases; sepsis; biomarkers

Submitted May 17, 2021. Accepted for publication Jun 18, 2021.

doi: 10.21037/apm-21-1607

View this article at: https://dx.doi.org/10.21037/apm-21-1607

\section{Introduction}

The 2020 COVID-19 pandemic has highlighted the major threat to human health imposed by infectious disease (1-3). Current clinical research on infectious diseases mainly focuses on three areas; the development of specific tests for diagnosis, especially modern molecular diagnostic techniques (4); the identification of co-infections, such as bacterial infections secondary to viral infections (5); and the monitoring of changes of disease during treatment and use of antibiotics (6). Procalcitonin (PCT) is a protein that consists of 116 amino acids and is the peptide precursor of calcitonin (6). PCT is used as a marker indicating the severity of bacterial infections, and increases significantly in the presence of sepsis and severe disease (7). As many bacterial infections can be secondary to non-bacterial infections, it is necessary to clarify the origin of infection in clinical practice so that appropriate antibiotic treatment can be applied and monitored. Many studies have observed the application of PCT in patients with infectious disease, and the 2020 COVID-19 outbreak has increased attention (8). Therefore, in addition to the research on PCT in common 
Table 1 Literature type

\begin{tabular}{lcc}
\hline Literature & Records & Percentage \\
\hline Article & 690 & 69.3 \\
Review & 111 & 11.1 \\
Letter & 97 & 9.7 \\
Meeting abstract & 55 & 5.5 \\
Editorial material & 37 & 3.7 \\
Proceedings paper & 29 & 2.9 \\
Correction & 5 & 0.5 \\
Early access & 5 & 0.5 \\
Book chapter & 1 & 0.1 \\
Retraction & 1 & 0.1 \\
\hline
\end{tabular}

infections, we should also pay attention to the current research status of PCT in infectious diseases. Different from some meta-analyses about the PCT in infectious diseases, the purpose of this study was to analyze relevant literature in the field of infectious disease to provide a general view on this field and to understand current trends and propose topics for further studies.

\section{Methods}

\section{Data source}

We used the Science Citation Index Expanded (SCI-E) database in the Web of Science Core Collection (WOSCC) as the data source.

\section{Retrieval method}

A subject search strategy was used with the search term "procalcitonin", while at the same time, the search scope was limited to the term "infectious diseases". The time range of the search literature was 1900 to the final search date of this research (May 7th, 2021), and the language of publication was limited to English.

\section{Analysis method}

The full record of the search results and cited references was exported in plain text format, and Citespace software was used to analyze the annual publication status, country/ institution distribution, journal distribution, author distribution, and keywords of literature related to the application of procalcitonin in infectious diseases.

\section{Statistical analysis}

This is a descriptive study and all data were expressed as number and percentage. No statistical comparison was conducted.

\section{Results}

\section{Basic results}

The search results showed a total of 996 related research documents, of which 690 were original articles, 111 review articles, 97 letters to editors, 55 meeting abstracts, 37 editorial materials, 29 proceedings papers, five early access articles, five corrections, one book, and one retraction (Tables 1,2, Figure 1). The total citation frequency of these documents was 24,895 times, the h-index count was 73 , and the average number of citations per item was 24.99 (Figure 2). Judging from the results of the annual distribution of the number of papers, the number of related papers published showed a clear increasing trend, especially in 2020 (Figure 1). The citation frequency of papers in this field also increased year-by-year (Figure 2).

\section{Distribution of countries and institutions}

We used CiteSpace V software to draw a national visualization map (Figure 3) and an institution visualization map (Figure 4), and the results show that the top five countries for the number of papers published were the United States, China, France, Spain, and Germany, and the top five countries in terms of centrality were the United States, Germany, the United Kingdom, France, and the Netherlands (Tables 3 and 4). The top five research institutions publishing related papers were the University of Basel, Kantonsspital Aarau, Baylor College of Medicine, Aarhus University Hospital, and Harvard University. However, cooperation between institutions was rare, and the two institutions with the highest centrality were Aarhus University Hospital and Harvard University, each with a centrality score of only 0.03 (Tables 5 and 6).

\section{Authors}

The author analysis results showed that the distribution of 
Table 2 Annual distribution of related papers

\begin{tabular}{|c|c|c|}
\hline Publication year & Records & Percentage (\%) \\
\hline 2021 & 35 & 3.5 \\
\hline 2020 & 107 & 10.7 \\
\hline 2019 & 76 & 7.6 \\
\hline 2018 & 74 & 7.4 \\
\hline 2017 & 68 & 6.8 \\
\hline 2016 & 70 & 7.0 \\
\hline 2015 & 58 & 5.8 \\
\hline 2014 & 64 & 6.4 \\
\hline 2013 & 65 & 6.5 \\
\hline 2012 & 56 & 5.6 \\
\hline 2011 & 52 & 5.2 \\
\hline 2010 & 43 & 4.3 \\
\hline 2009 & 24 & 2.4 \\
\hline 2008 & 33 & 3.3 \\
\hline 2007 & 40 & 4.0 \\
\hline 2006 & 20 & 2.0 \\
\hline 2005 & 21 & 2.1 \\
\hline 2004 & 21 & 2.1 \\
\hline 2003 & 15 & 1.5 \\
\hline 2002 & 9 & 0.9 \\
\hline 2001 & 9 & 0.9 \\
\hline 2000 & 11 & 1.1 \\
\hline 1999 & 8 & 0.8 \\
\hline 1998 & 8 & 0.8 \\
\hline 1997 & 5 & 0.5 \\
\hline 1996 & 2 & 0.2 \\
\hline 1995 & 2 & 0.2 \\
\hline
\end{tabular}

authors in this field was also relatively scattered. There were only two authors with more than 10 publications: Schuetz $\mathrm{P}$ and Mueller B, and only three with a centrality score of more than 0.01: Christcrain M, Beishuizen A, and Jong ED, suggesting that there is little cooperation between authors (Tables 7,8, Figure 5). However, related papers are cited frequently, with those of six authors being cited more than 100 times: Schuetz P, Christ-Crain M, Assicot M, Simon L, Muller B, and Meisner M (Table 9). The cited authors were relatively concentrated, and there were three authors with a centrality score greater than 0.1: Bone RC, Becker $\mathrm{KI}$, and Assicot M (Table 10, Figure 6). The co-citation analysis of the author's literature (Figure 7) shows significant chronology and centrality (Figure 7).

\section{Distribution of journals}

The literature in this study involved 74 journals, of which 17 had published more than 20 papers on this subject. These journals published a total of 739 articles, accounting for $74.2 \%$ of the total literature (Table 11). The journals cited more than 400 times include Clin Infect Dis, Lancet, and Crit Care Med, all of which are top authoritative journals in this field or comprehensive fields (Table 12). Journals with centrality greater than 0.05 were Ann Intern Med, Clin Chem Lab Med, Am 7 Clin Pathol, Acta Paediatr, and Am 7 Med (Table 13).

\section{Keywords reflect the research hotspots and frontiers in this field}

CiteSpace V software was used to output the keyword cooccurrence map (Figure 8) and the top five keywords with frequency were procalcitonin, C-reactive protein, sepsis,

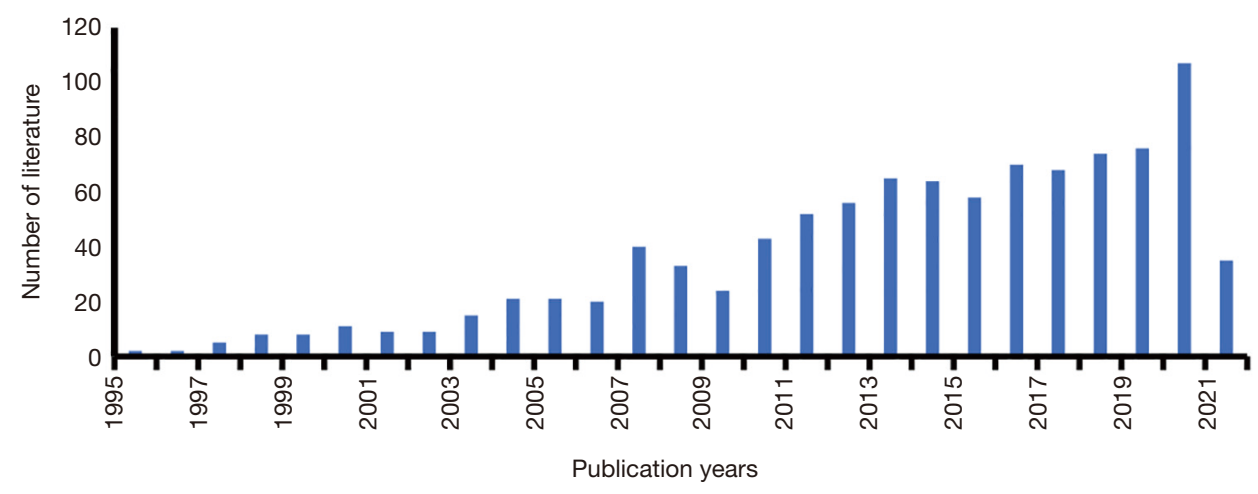

Figure 1 Trends in the number of annual papers published. 


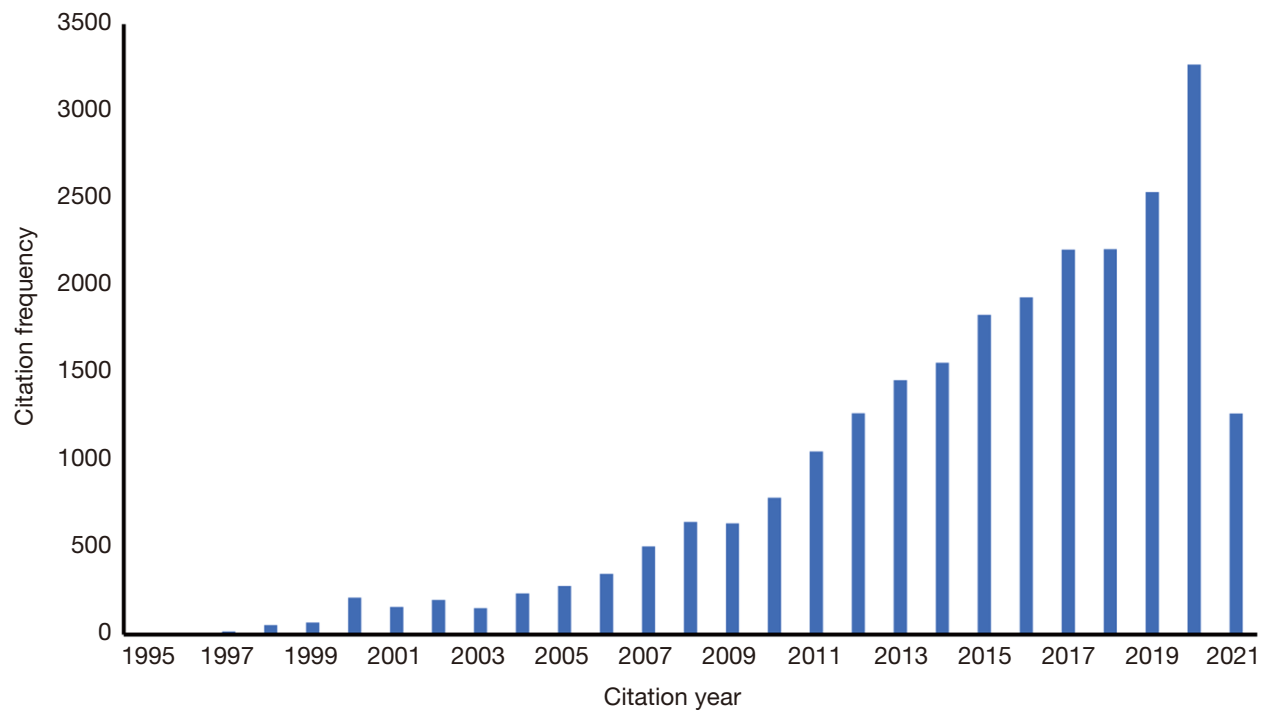

Figure 2 Trends in the frequency of citations of papers in this field each year.

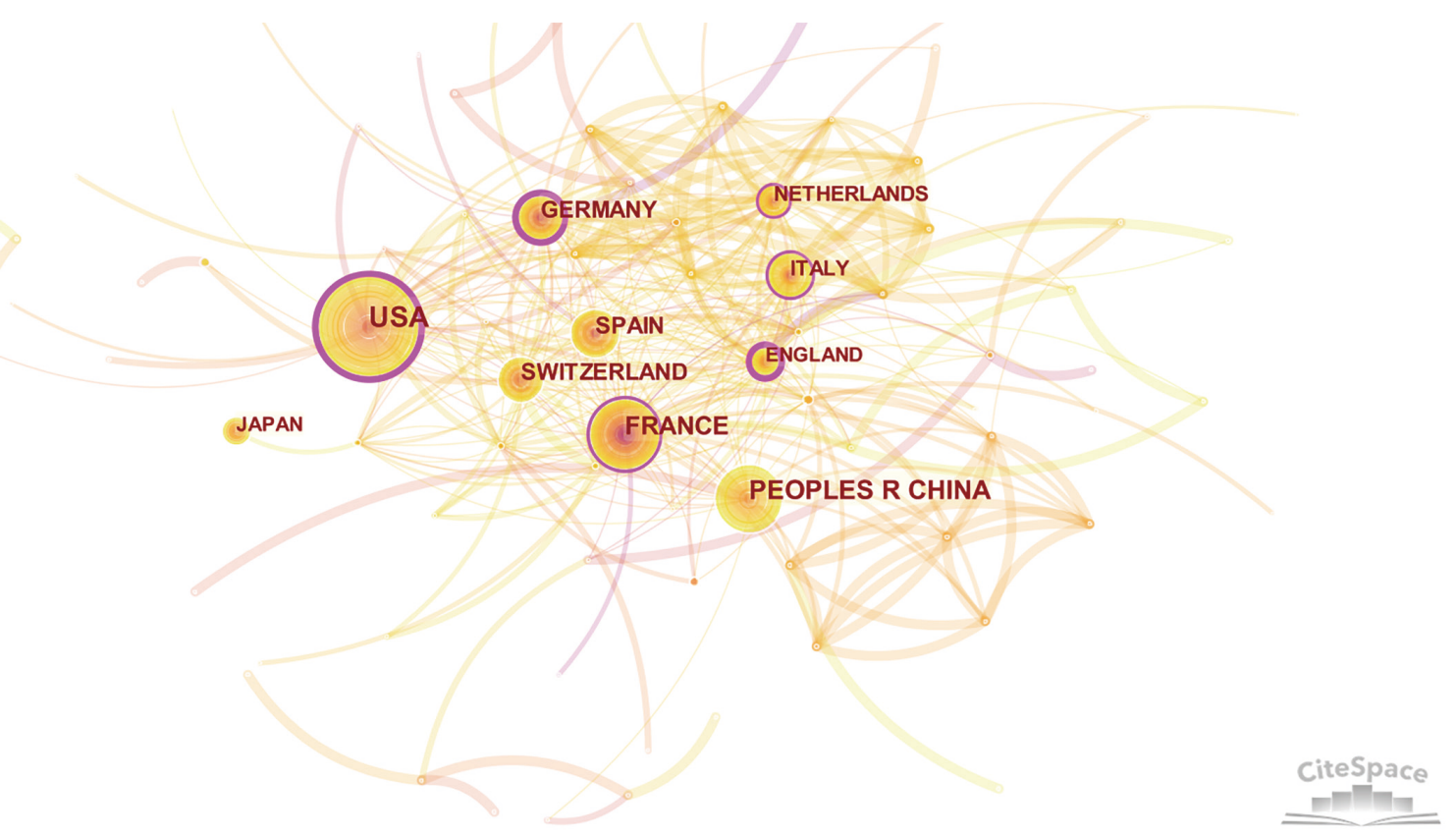

Figure 3 Country visualization map. The knot and connection between countries are few, indicating that the cooperation between countries is rare.

biomarker, and infection (Table 14). The top five keywords for centrality were sepsis, c reactive protein, procalcitonin, biomarker, and pneumonia (Table 15), and using CiteSpace to perform Burst detection on keywords with high frequency showed high-frequency keywords obviously changed with time (Figure 9).

\section{Discussion}

PCT is widely used in clinical practice, especially in emergency and critical care medicine, to quickly identify the possibility of bacterial infection. Until February 2019, there were 17 guidelines on the application of PCT, of 

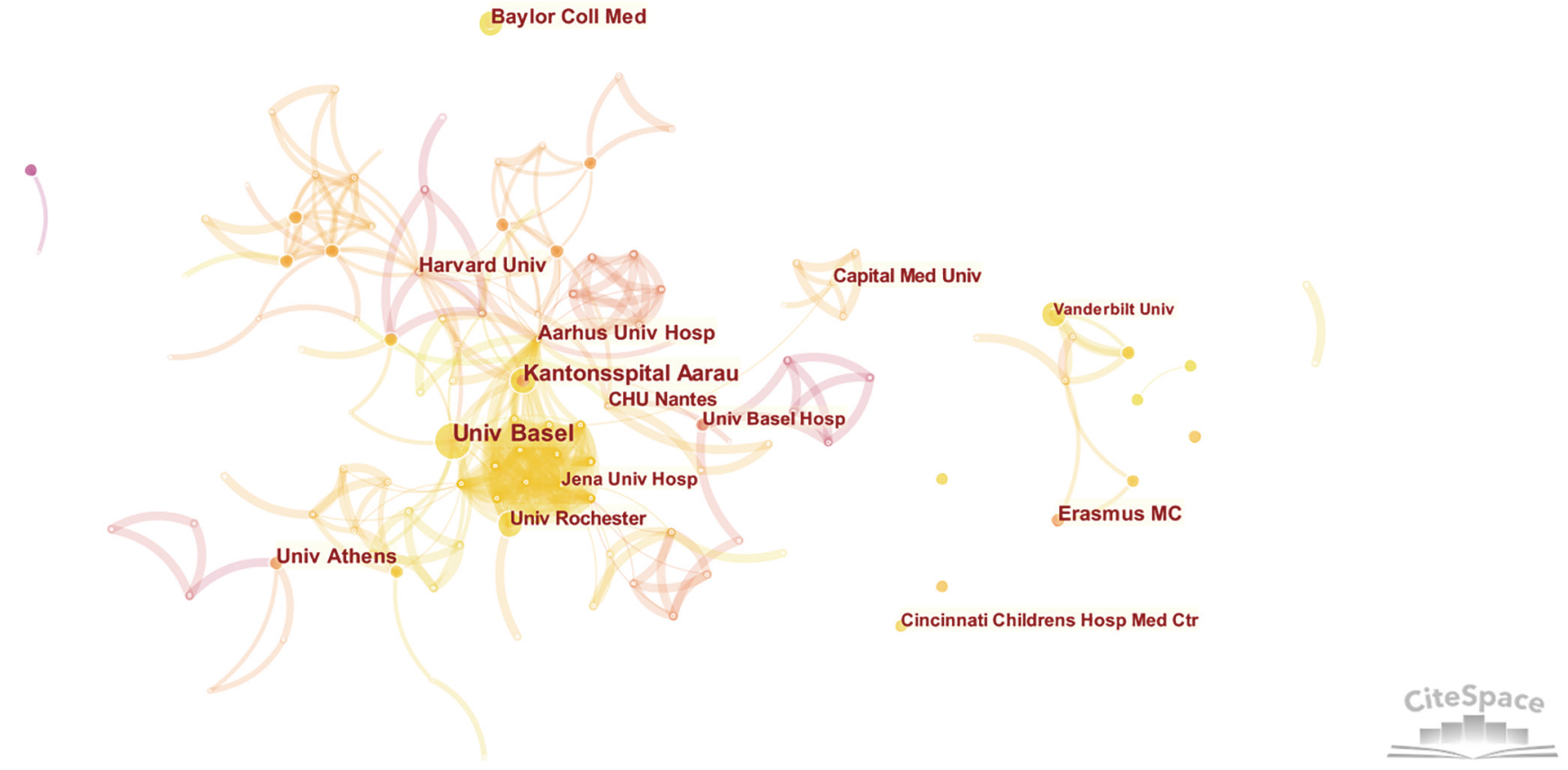

Figure 4 Visual map of the organization. There are relatively few knot and connections between knots, suggesting that there is little cooperation between institutions.

Table 3 Top 10 countries for numbers of papers published

\begin{tabular}{lcc}
\hline Rank & Country & Frequency \\
\hline 1 & USA & 192 \\
2 & China & 131 \\
3 & France & 94 \\
4 & Spain & 83 \\
5 & Germany & 77 \\
6 & Switzerland & 69 \\
7 & Netherlands & 62 \\
8 & Italy & 59 \\
9 & Japan & 45 \\
10 & England & 44 \\
\hline
\end{tabular}

which there were 12 recommending the use of PCT for the diagnosis or treatment of bacterial infections, one guideline holding this was not necessary, and four which held that there was insufficient evidence to recommend or not recommend its use (9). However, these studies mainly
Table 4 Top 10 countries for centrality

\begin{tabular}{lcc}
\hline Rank & Country & Centrality \\
\hline 1 & USA & 0.23 \\
2 & Germany & 0.20 \\
3 & England & 0.20 \\
4 & France & 0.17 \\
5 & Netherlands & 0.16 \\
6 & Italy & 0.13 \\
7 & Spain & 0.10 \\
8 & Brazil & 0.09 \\
9 & Egypt & 0.09 \\
10 & Slovakia & 0.09 \\
\hline
\end{tabular}

observed the application of PCT in infection in other fields of clinical medicine (10), and the range and depth of research into the role of PCT specifically in infectious disease is unclear. In response to this, we limited our search scope to the specific field "infectious diseases" and the 
Table 5 Top 10 institutions for number of papers published

\begin{tabular}{llc}
\hline Rank & Institutions & Frequency \\
\hline 1 & University Basel & 17 \\
2 & Kantonsspital Aarau & 14 \\
3 & Baylor College of Medicine & 11 \\
4 & Aarhus University Hospital & 10 \\
5 & Harvard University & 10 \\
6 & Erasmus MC & 10 \\
7 & University Athens & 10 \\
8 & Capital Medical University & 9 \\
9 & CHU Nantes & 9 \\
10 & Univ Rochester & 9 \\
\hline
\end{tabular}

Table 6 Top 10 institutions by centrality

\begin{tabular}{llc}
\hline Rank & Institutions & Centrality \\
\hline 1 & Aarhus University Hospital & 0.03 \\
2 & Harvard University & 0.03 \\
3 & Univ Basel & 0.01 \\
4 & Kantonsspital Aarau & 0.01 \\
5 & Capital Medical University & 0.01 \\
6 & Jena University Hospital & 0.01 \\
7 & University Basel Hospital & 0.01 \\
8 & Taiwan University Hospital & 0.01 \\
9 & University Paris 06 & 0.01 \\
10 & Hannover Medical School & 0.01 \\
\hline
\end{tabular}

results showed that there is less study in this than in related fields. The total number of publications was only 996 (as of May 7, 2021, English literature), of which only 690 were original articles. This may be because some infectious diseases are easy to diagnose and have more reasonable indicators for monitoring $(11,12)$, and there is no need for the use of PCT in diagnosis or to guide treatment. However, the substantial increase in related papers in 2020 suggests its increased use as an indicator of infectious disease is not in a small way related to the COVID-19 pandemic, on which more than 20 papers have been published $(8,13)$.

Our results show that most research in this field arises from several institutions in Europe and the United States, and while most researchers in the field also belong to these
Table 7 Top 10 authors and number of papers published

\begin{tabular}{lcc}
\hline Rank & Authors & Frequency \\
\hline 1 & Schuetz P & 22 \\
2 & Mueller B & 13 \\
3 & Julianjimenez A & 9 \\
4 & Bohuon C & 7 \\
5 & Christcrain M & 6 \\
6 & Beishuizen A & 4 \\
7 & Prat C & 4 \\
8 & Gendrel D & 4 \\
9 & Musher Dm & 4 \\
10 & Gilbert Dn & 4 \\
\hline
\end{tabular}

Table 8 Top 3 authors for centrality

\begin{tabular}{lcc}
\hline Rank & Authors & Centrality \\
\hline 1 & Christcrain M & 0.02 \\
2 & Beishuizen A & 0.01 \\
3 & Jong ED & 0.01 \\
\hline \multicolumn{2}{l}{ There are only three authors with a centrality score of 0.01.}
\end{tabular}

institutions, there appeared to be little collaboration in terms of authorship between them. This situation is no different in China, which produces many publications, with little evidence of international collaboration. One reason for this may be that there are currently few countries capable of carrying out relevant research in the field of infectious disease (14), which may in turn be due to the high costs in maintaining the strict quality control and biosafety measures required to operate an infectious disease research laboratory $(15,16)$. Despite this, network collaboration is increasing, and has made it easier to carry out multi-center research on many common diseases, rare diseases, and infectious diseases (17). The implementation of networks connecting all parts of the world may also be more conducive to the prevention and control of infectious diseases in poor countries and regions which are unable to establish their own research facilities. In terms of journals, research results in this field are more likely to be published in more detailed professional journals, but high-quality research is more likely to be published in top comprehensive journals and critical care journals. This may be because these studies have more extensive reference value, or the diseases involved are 


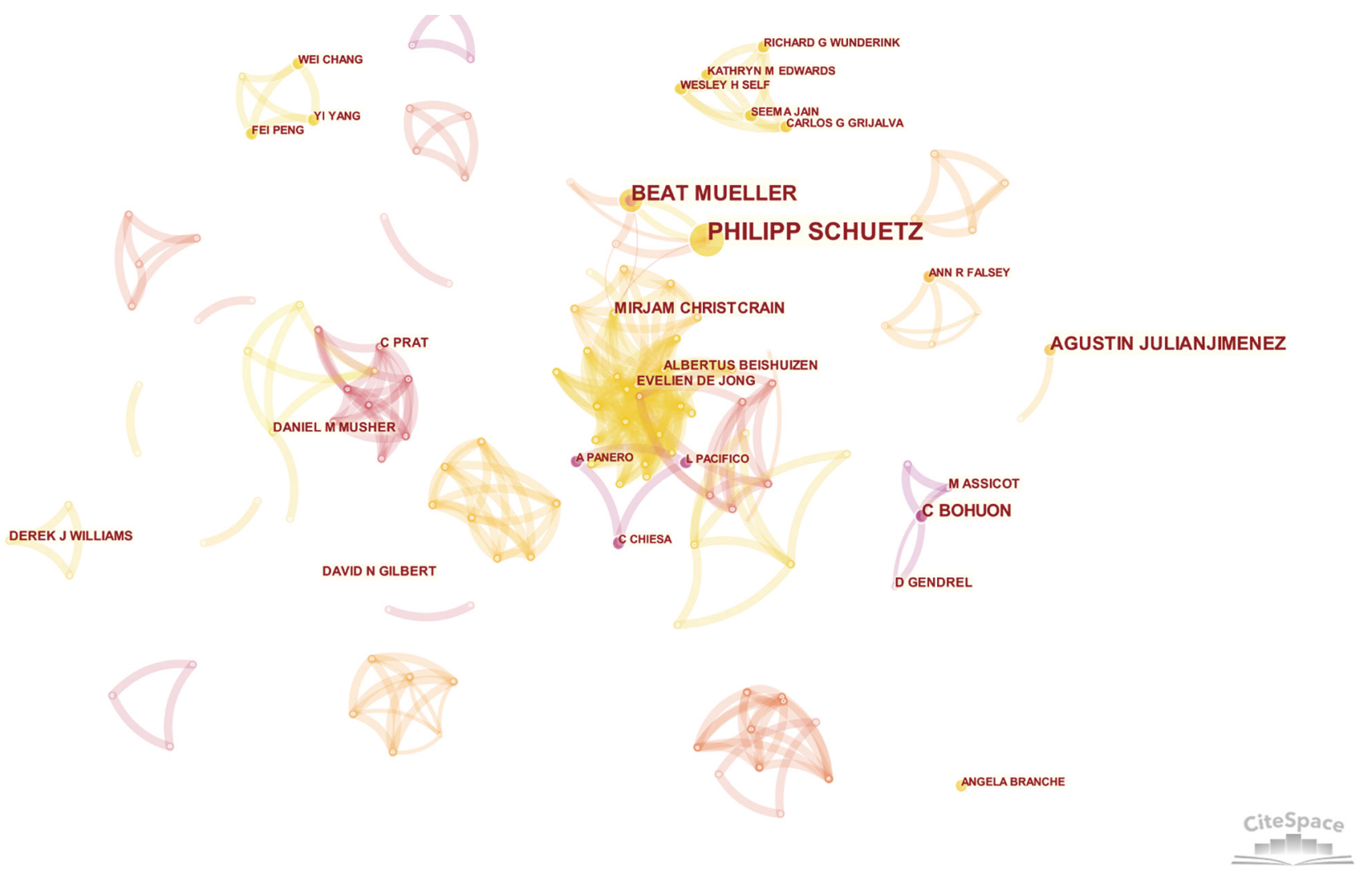

Figure 5 Author co-operation visualization map, which clearly shows that there are few connections between knots.

Table 9 Top 10 authors cited in literature

\begin{tabular}{lcc}
\hline Rank & Authors & Frequency \\
\hline 1 & Schuetz P & 231 \\
2 & Christ-Crain M & 184 \\
3 & Assicot M & 148 \\
4 & Simon L & 144 \\
5 & Muller B & 116 \\
6 & Meisner M & 101 \\
7 & Bouadma L & 96 \\
8 & [Anonymous] & 94 \\
9 & Bone RcC & 94 \\
10 & Gendrel D & 90 \\
\hline
\end{tabular}

"Anonymous" often refers to comments from journals.

more serious, and the disease covers more people.

In addition to the term procalcitonin, the most frequently used keywords mainly concerned biomarkers, severe illness, and sepsis, suggesting that many studies
Table 10 Top 10 co-cited authors of centrality

\begin{tabular}{llc}
\hline Rank & Authors & Centrality \\
\hline 1 & Bone RC & 0.2 \\
2 & Becker KI & 0.17 \\
3 & Assicot M & 0.11 \\
4 & Meisner M & 0.08 \\
5 & Giamarellos-Bourboulis EJ & 0.07 \\
6 & Chiesa C & 0.07 \\
7 & Dandona P & 0.07 \\
8 & Gendrel D & 0.07 \\
9 & Muller B & 0.07 \\
10 & Simon L & 0.07 \\
\hline
\end{tabular}

are related to post-infection sepsis. Moreover, we have also seen significant changes in the use of keywords over time, suggesting that the focus of research is changing, with the current focus on critical illness-related research, especially sepsis $(18,19)$. Regarding the use of PCT, most 


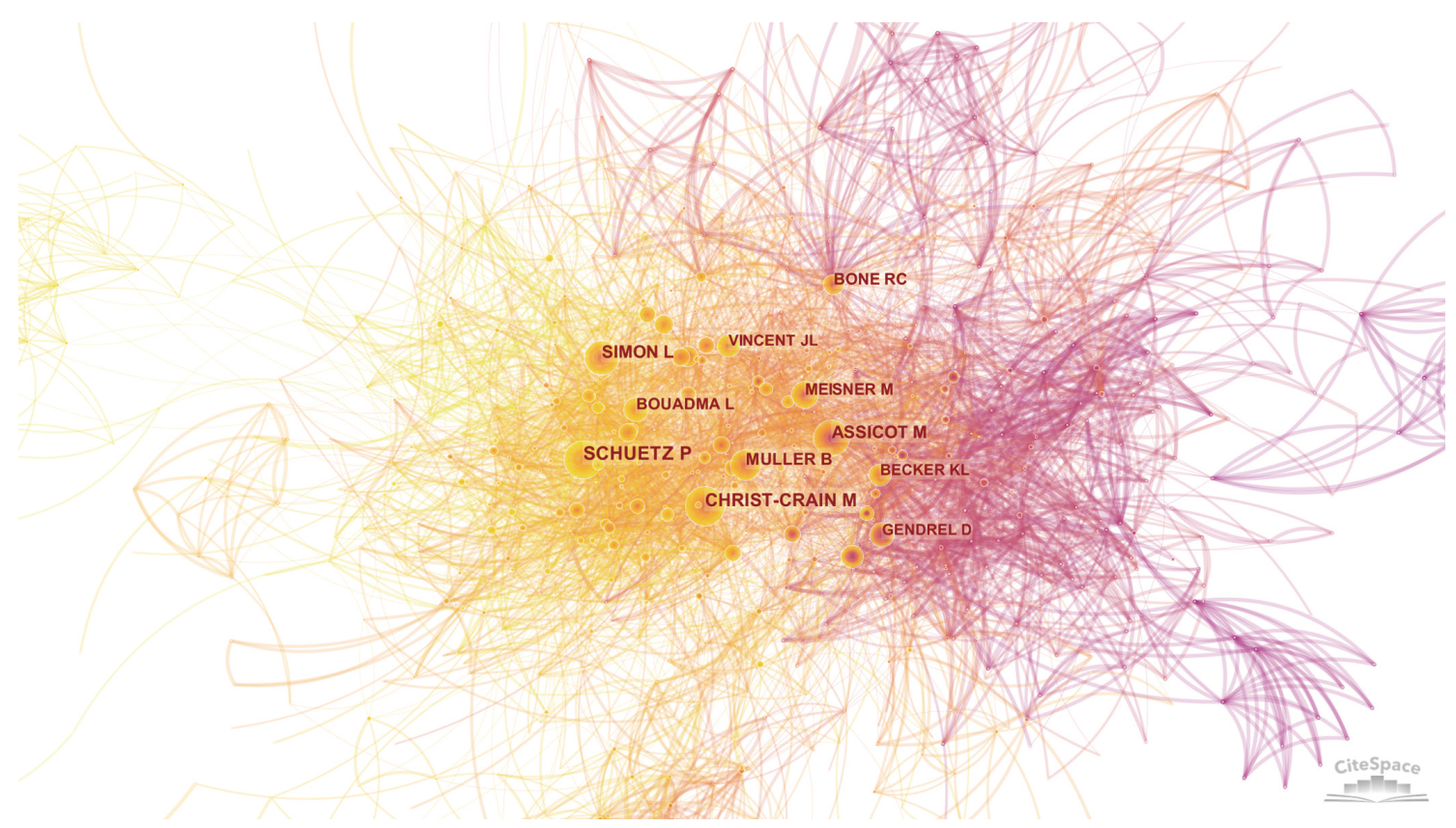

Figure 6 Author's co-cited visualization map.
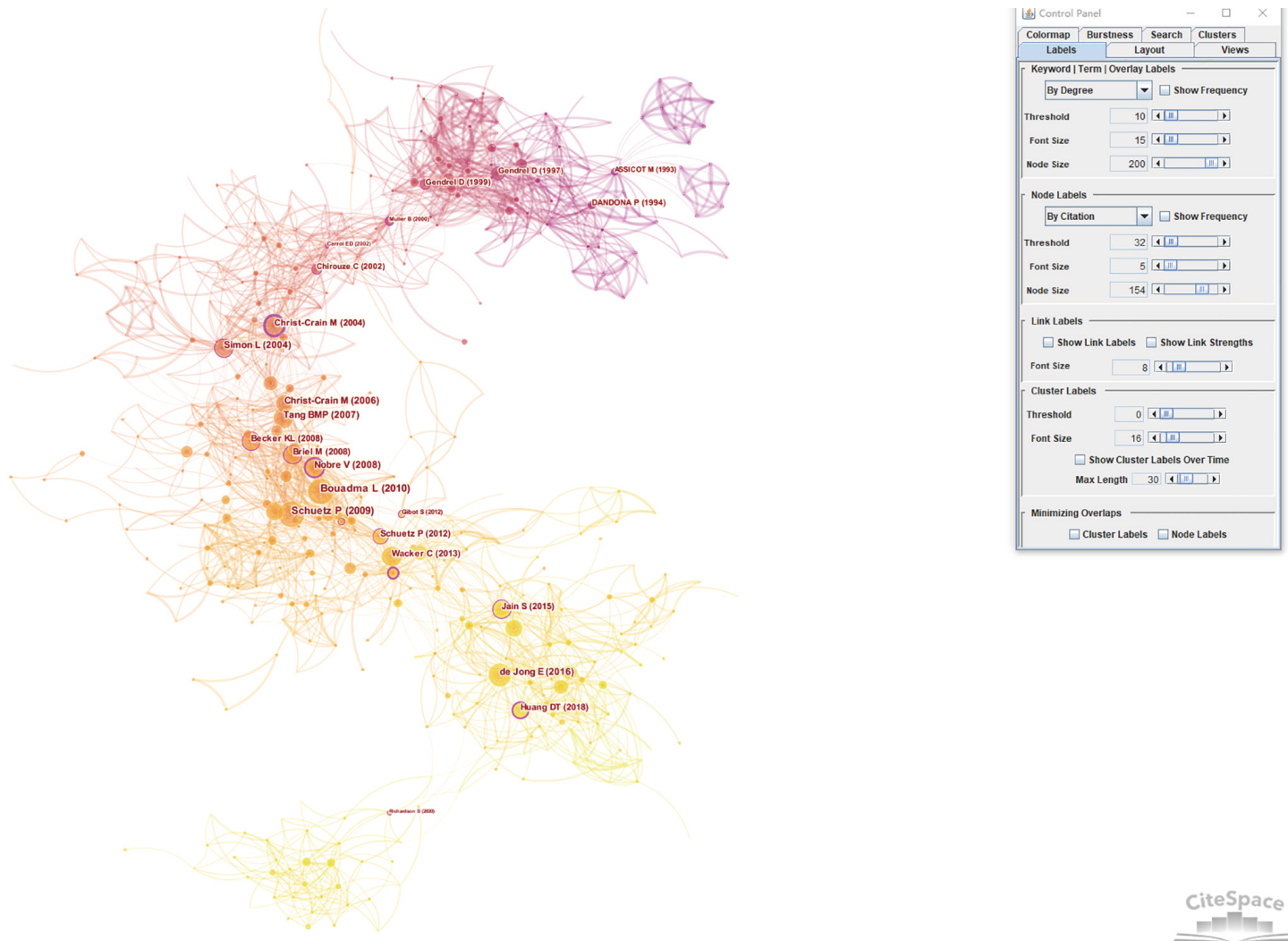

Figure 7 The document co-cited image. The figure clearly shows the chronology and centrality. 
Table 11 Top 17 journals by number of published papers

\begin{tabular}{|c|c|c|c|}
\hline Rank & Journals & Records & Percentage \\
\hline 2 & Clinical Infectious Diseases & 84 & 8.4 \\
\hline 3 & Infection & 68 & 6.8 \\
\hline 4 & Pediatric Infectious Disease Journal & 65 & 6.5 \\
\hline 6 & Journal of Infection & 54 & 5.4 \\
\hline 7 & International Journal of Infectious Diseases & 41 & 4.1 \\
\hline 8 & International Journal of Antimicrobial Agents & 38 & 3.8 \\
\hline 9 & Clinical Microbiology and Infection & 30 & 3.0 \\
\hline 12 & Surgical Infections & 30 & 3.0 \\
\hline 13 & Diagnostic Microbiology and Infectious Disease & 27 & 2.7 \\
\hline 14 & Journal of Infection and Chemotherapy & 27 & 2.7 \\
\hline 15 & Expert Review of Anti-Infective Therapy & 24 & 2.4 \\
\hline 16 & Enfermedades Infecciosas Y Microbiologia Clinica & 22 & 2.2 \\
\hline 17 & Current Opinion in Infectious Diseases & 20 & 2.0 \\
\hline
\end{tabular}

Table 12 Top 10 journals by citation frequency

\begin{tabular}{lcc}
\hline Rank & Journals & Records \\
\hline 1 & Clin Infect Dis & 613 \\
2 & Lancet & 457 \\
3 & Crit Care Med & 453 \\
4 & Intens Care Med & 388 \\
5 & New Engl J Med & 376 \\
6 & Jama-J Am Med Assoc & 346 \\
7 & Crit Care & 335 \\
8 & Am J Resp Crit Care & 304 \\
9 & Chest & 291 \\
10 & Lancet Infect Dis & 272 \\
\hline
\end{tabular}

guidelines currently recommend that bacterial infections are not supported when serum PCT $<0.05 \mu \mathrm{g} / \mathrm{L}$, while serum PCT $>2.00 \mu \mathrm{g} / \mathrm{L}$ suggests sepsis, and indicates a serious condition. However, attention should be paid to other clinical manifestations and indicators, and an
Table 13 Top 10 journals cited by centrality

\begin{tabular}{lcc}
\hline Rank & Journals & Centrality \\
\hline 1 & Ann Intern Med & 0.08 \\
2 & Clin Chem Lab Med & 0.08 \\
3 & Am J Clin Pathol & 0.08 \\
4 & Acta Paediatr & 0.07 \\
5 & Am J Med & 0.07 \\
6 & Brit Med J & 0.05 \\
7 & Am J Trop Med Hyg & 0.05 \\
8 & Brit J Anaesth & 0.05 \\
9 & Clin Chem & 0.04 \\
10 & Antimicrob Agents Ch & 0.04 \\
\hline
\end{tabular}

increase in serum PCT caused by local infection and noninfectious factors should be excluded. Dynamic serum PCT monitoring is very important for disease evaluation and prognostic judgment, especially in critically ill patients, and can guide the use of clinical antibacterial drugs. These 


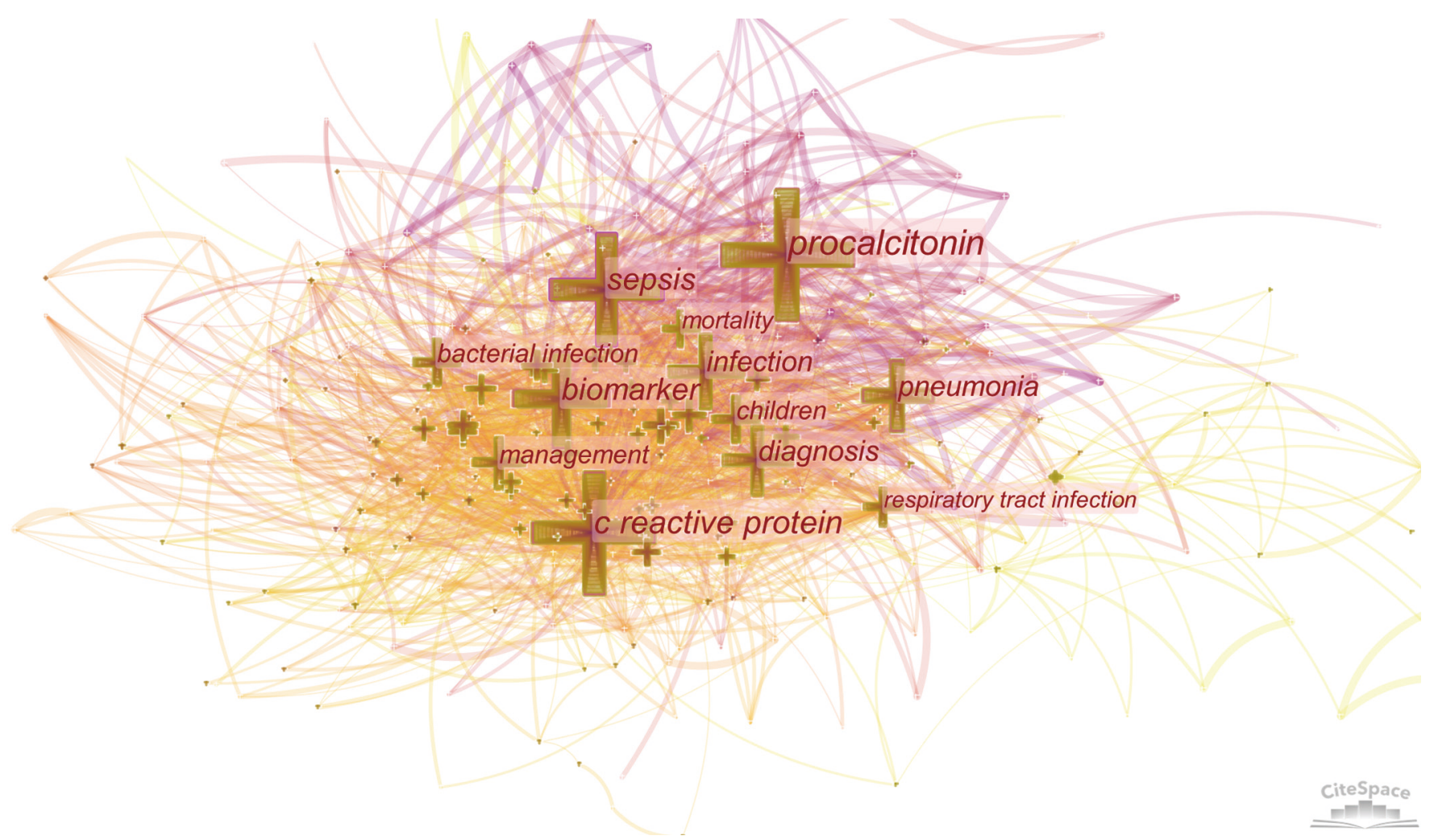

Figure 8 Keyword co-occurrence map. Note: The obvious synonyms were merged when making the keyword map. Such as: sepsis \# septic shock, c reactive protein \# c-reactive protein, and procalcitonin \# serum procalcitonin.

Table 14 Top 10 keywords by frequency

\begin{tabular}{lcc}
\hline Rank & Key words & Frequency \\
\hline 1 & Procalcitonin & 566 \\
2 & C reactive protein & 338 \\
3 & Sepsis & 295 \\
4 & Biomarker & 260 \\
5 & Infection & 182 \\
6 & Pneumonia & 178 \\
7 & Diagnosis & 158 \\
8 & Management & 96 \\
9 & Children & 93 \\
10 & Bacterial infection & 92 \\
\hline
\end{tabular}

drugs are not used when serum PCT $<0.25 \mu \mathrm{g} / \mathrm{L}$ excludes bacterial infection, and after treatment, when serum PCT is less than $0.50 \mu \mathrm{g} / \mathrm{L}$ or the peak reduction is $\geq 80 \%$, and if clinical manifestations indicate, discontinuing antibacterial
Table 15 Top 10 keywords for centrality

\begin{tabular}{lcc}
\hline Rank & Key words & Centrality \\
\hline 1 & Sepsis & 0.24 \\
2 & C reactive protein & 0.20 \\
3 & Procalcitonin & 0.18 \\
4 & Biomarker & 0.13 \\
5 & Pneumonia & 0.13 \\
6 & CovID-19 & 0.09 \\
7 & Infection & 0.08 \\
8 & Diagnosis & 0.08 \\
9 & Children & 0.07 \\
10 & Interleukin 6 & 0.06 \\
\hline
\end{tabular}

drugs may be considered $(20,21)$.

The chief limitation of this research is that the scope of the document search was limited to "infectious diseases", which may have produced inconsistencies in the 
Top 25 keywords with the strongest citation bursts

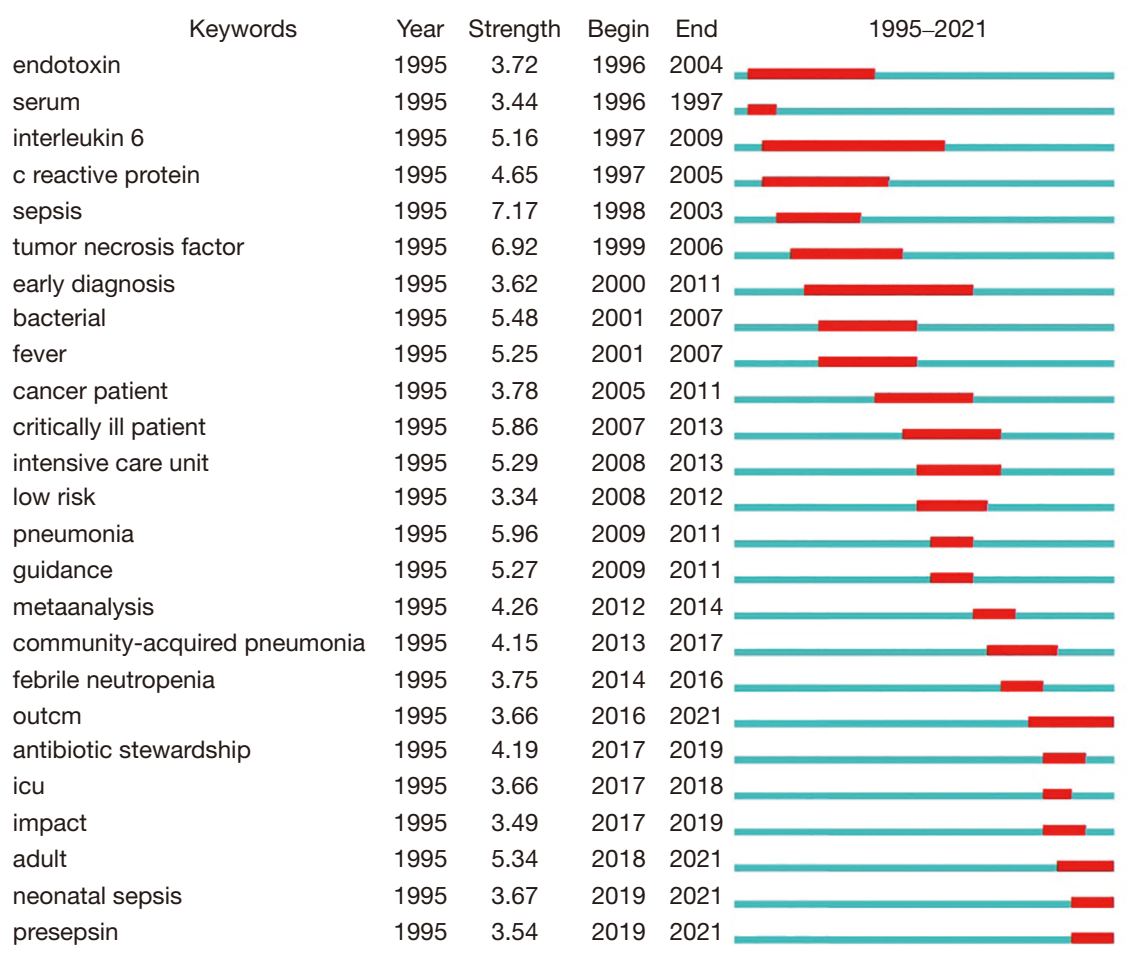

Figure 9 Top 25 keywords with the strongest citation bursts.

classification of publications, and some may be missed. The results also suggest that the classification of documents should be more accurate to avoid confusion and repetition, which will be conducive to accurate retrieval and results.

\section{Acknowledgments}

Funding: None.

\section{Footnote}

Conflicts of Interest: All authors have completed the ICMJE uniform disclosure form (available at https://dx.doi. org/10.21037/apm-21-1607). The authors have no conflicts of interest to declare.

Ethical Statement: The authors are accountable for all aspects of the work in ensuring that questions related to the accuracy or integrity of any part of the work are appropriately investigated and resolved.

Open Access Statement: This is an Open Access article distributed in accordance with the Creative Commons Attribution-NonCommercial-NoDerivs 4.0 International License (CC BY-NC-ND 4.0), which permits the noncommercial replication and distribution of the article with the strict proviso that no changes or edits are made and the original work is properly cited (including links to both the formal publication through the relevant DOI and the license). See: https://creativecommons.org/licenses/by-nc-nd/4.0/.

\section{References}

1. Jones KE, Patel NG, Levy MA, et al. Global trends in emerging infectious diseases. Nature 2008;451:990-3.

2. Murray KA, Preston N, Allen T, et al. Global biogeography of human infectious diseases. Proc Natl Acad Sci U S A 2015;112:12746-51.

3. Bedford J, Enria D, Giesecke J, et al. COVID-19: towards controlling of a pandemic. Lancet 2020;395:1015-8.

4. Yang $S$, Rothman RE. PCR-based diagnostics for infectious diseases: uses, limitations, and future applications in acutecare settings. Lancet Infect Dis 2004;4:337-48.

5. Langford BJ, So M, Raybardhan S, et al. Bacterial co- 
infection and secondary infection in patients with COVID-19: a living rapid review and meta-analysis. Clin Microbiol Infect 2020;26:1622-9.

6. Stocker M, van Herk W, El Helou S, et al. Procalcitoninguided decision making for duration of antibiotic therapy in neonates with suspected early-onset sepsis: a multicentre, randomised controlled trial (NeoPIns). Lancet 2017;390:871-81.

7. Wirz Y, Meier MA, Bouadma L, et al. Effect of procalcitonin-guided antibiotic treatment on clinical outcomes in intensive care unit patients with infection and sepsis patients: a patient-level meta-analysis of randomized trials. Crit Care 2018;22:191.

8. Lippi G, Plebani M. Procalcitonin in patients with severe coronavirus disease 2019 (COVID-19): A meta-analysis. Clin Chim Acta 2020;505:190-1.

9. Tujula B, Hamalainen S, Kokki H, et al. Review of clinical practice guidelines on the use of procalcitonin in infections. Infect Dis (Lond) 2020;52:227-34.

10. Hamade B, Huang DT. Procalcitonin: Where Are We Now? Crit Care Clin 2020;36:23-40.

11. Miller JM, Binnicker MJ, Campbell S, et al. A Guide to Utilization of the Microbiology Laboratory for Diagnosis of Infectious Diseases: 2018 Update by the Infectious Diseases Society of America and the American Society for Microbiology. Clin Infect Dis 2018;67:813-6.

12. Mongan AE, Tuda JSB, Runtuwene LR. Portable sequencer in the fight against infectious disease. J Hum Genet 2020;65:35-40.

13. Ahmed S, Jafri L, Hoodbhoy Z, et al. Prognostic Value of Serum Procalcitonin in COVID-19 Patients: A Systematic
Review. Indian J Crit Care Med 2021;25:77-84.

14. Roberts CC. Emerging infectious disease laboratory and diagnostic preparedness to accelerate vaccine development. Hum Vaccin Immunother 2019;15:2258-63.

15. Head MG, Brown RJ, Clarke SC. Research investments for UK infectious disease research 1997-2013: A systematic analysis of awards to UK institutions alongside national burden of disease. J Infect 2018;76:11-9.

16. Mercer A. Protection against severe infectious disease in the past. Pathog Glob Health 2021;115:151-67.

17. Turner AK, Wages RK, Nadeau K, et al. The Infectious Disease Network (IDN): Development and Use for Evaluation of Potential Ebola Cases in Georgia. Disaster Med Public Health Prep 2018;12:765-71.

18. Mierzchała-Pasierb M, Lipinska-Gediga M. Sepsis diagnosis and monitoring - procalcitonin as standard, but what next? Anaesthesiol Intensive Ther 2019;51:299-305.

19. Jekarl DW, Lee S, Kim M, et al. Procalcitonin as a prognostic marker for sepsis based on SEPSIS-3. J Clin Lab Anal 2019;33:e22996.

20. Rhodes A, Evans LE, Alhazzani W, et al. Surviving Sepsis Campaign: International Guidelines for Management of Sepsis and Septic Shock: 2016. Intensive Care Med 2017;43:304-77.

21. Lee CC, Kwa ALH, Apisarnthanarak A, et al. Procalcitonin (PCT)-guided antibiotic stewardship in AsiaPacific countries: adaptation based on an expert consensus meeting. Clin Chem Lab Med 2020;58:1983-91.

(English Language Editor: J. Draper)
Cite this article as: Zhang $\mathrm{Y}$, Zhang J, Zhao L, Zhao N, Zhang Y, Zhang J, Wang S. Procalcitonin in infectious diseases: a bibliometric analysis. Ann Palliat Med 2021;10(7):8003-8014. doi: 10.21037/apm-21-1607 